УДК

DOI https://doi.org/10.51989/NUL.2021.4.29

\title{
ОСОБЛИВОСТІ КОНТРОЛЮ ЗА ВИКОРИСТАННЯМ ТА ОХОРОНОЮ ЗЕМЕЛЬ В УМОВАХ ДЕЦЕНТРАЛІЗАЦІЇ ВЛАДИ ТА РОЗВИТКУ ГРОМАДЯНСЬКОГО СУСПІЛЬСТВА В УКРАЇНI
}

\author{
Самородов Артем Сергійович, \\ кандидат юридичних наук, \\ провідний науковий співробітник \\ Київського регіонального центру Національної академії правових наук України
}

У статті на основі аналізу наукових джерел та останніх законодавчих змін досліджуються основні види контролю за використанням та охороною земель в Україні. Проведено детальний аналіз дієвості та ефективності державного та громадського контролю у цій сфері.

Автором проаналізовано положення Закону України «Про внесення змін до деяких законодавчих актів України щодо вдосконалення системи управління та дерегуляції у сфері земельних відносин» у контексті внесених цим Законом змін до законодавчих актів щодо регулювання відносин у сфері контролю за використанням та охороною земель.

Аргументовано неузгодженість Закону України «Про внесення змін до деяких законодавчих актів України щодо вдосконалення системи управління та дерегуляції у сфері земельних відносин» з конституційними принципами формування повноважень органів місцевого самоврядування та участі громадянського суспільства в управлінні державними справами. Обґрунтовано необхідність вдосконалення земельного законодавства України у сфері контролю за використанням та охороною земель в Україні.

У результаті проведеного дослідження автор доходить висновку, що прийняття Закону України «Про внесення змін до деяких законодавчих актів України щодо вдосконалення системи управління та дерегуляції у сфері земельних відносин» не усунуло недоліки правового регулювання відносин у сфері використання та охорони земель, зокрема, щодо концентрації в одного і того ж суб'єкта владних повноважень - Держгеокадастру, управлінських, контрольних та наглядових повноважень у сфері земельних відносин.

у висновках автор зауважує, що перспективою подальших наукових розробок у напряму порушених проблемних питань може бути використання отриманих результатів у наступних дослідженнях для удосконалення правового регулювання відносин у сфері використання та охорони земель для реформування системи державного управління та дерегуляції у сфері земельних відносин.

Ключові слова: децентралізація влади, контроль за використанням та охороною земель, дерегуляція, інститути громадянського суспільства.

\section{Samorodov Artem. Particularities of control over the use and protection of land amidst decentralization of power and development of civil society in Ukraine}

The article, based on the analysis of scientific sources and the latest legislative changes, examines the main types of controloverl and use and protection in Ukraine. A detailed analysis of the effectiveness and efficiency of state and public control in this area. The author analyzes the provisions of the Law of Ukraine "On Amendments to Certain Legislative Acts of Ukraine on Improving the Management and Deregulation System in the Sphere of Land Relations" in the context of amendments to legislative acts on regulating relations in the field of land use control and protection. The inconsistency of the Law of Ukraine "On Amendments to Certain Legislative Acts of Ukraine on Improving the System of Management and Deregulation in the Sphere of Land Relations" with the constitutional principles of forming the powers of localself-government bodies and civil society participation in public administration is argued. The necessity of improving the land legislation of Ukraine in the field of control over the use and protection of lands in Ukraine is substantiated.

As a result of the study, the author concludes that the adoption of the Law of Ukraine "On Amendments to Certain Legislative Acts of Ukraine to Improve the Management and Deregulation of Land Relations" did not eliminate the shortcomings of legal regulation 
of relations in land use and protection, in particular and the same subject of power - the State Geocadastre, administrative, control and supervisory powers in the field of land relations.

In conclusion, the author notes that the prospect of further research in addressing the issues may be the use of the results in subsequent studies to improve the legal regulation of relations in the field of land use and protection to reform public administration and deregulation in land relations.

Key words: decentralization of power, control over land use and protection, deregulation, civil society institutions.

Сталий розвиток будь-якої сучасної держави, яка бажає бути суб'єктом міжнародних відносин, неможливий без укріплення державних інститутів, формування конкурентного бізнес-середовища та зрілого громадянського суспільства.

Попри розгалуженість сфер діяльності бізнесу та різноманіття формувань громадянського суспільства, протягом останніх десятирічь держава та її органи влади постійно намагалися централізувати владу та зміцнити вертикаль впливу на органи місцевого самоврядування. Наслідки такої централізації (іноді навіть намагань узурпації) ми відчули у неспроможності України подолати економічні кризи останніх років, у безпорадності державного апарату щодо розв'язання викликів зовнішньої агресії, у непослідовній реакції на пандемію тощо.

Розпочата в Україні децентралізація влади націлена на створення спроможних територіальних громад та дієвих органів місцевого самоврядування, здатних ефективно вирішувати ключові питання місцевого значення та задовольняти потреби платників податків, громадян та інвесторів. Зазначена реформа децентралізації була ретельно регламентована Концепцією реформи місцевого самоврядування та територіальної організації влади в Україні [1], серед головних етапів якої окреслені: законодавче врегулювання нової системи адміністративно-територіального устрою; формування законодавчої бази з питань діяльності органів місцевого самоврядування та органів виконавчої влади на новій територіальній основі з визначенням їх повноважень та ресурсного забезпечення відповідно до вимог цієї Концепції; утворення об'єднаних територіальних громад, спроможних самостійно або через органи місцевого самоврядування вирішувати питання місцевого значення; підвищення якості надання публічних послуг органами місцевого самоврядування об'єднаних територіальних громад і орга- нами виконавчої влади, розмежування їх повноважень та удосконалення системи планування території громад тощо.

Зазначені напрями свідчать про актуальність обраної теми дослідження, а також доцільність проведення подальших наукових розробок щодо пошуку та обґрунтування правового механізму та обсягу повноважень у сфері земельних відносин, які вкрай важливо передати на місця. Також важливо звернути увагу громад на необхідність взаємодії із зазначених питань з державою та підприємцями.

Одним із найважливіших напрямів регулювання земельних відносин, що сприяють ефективному використанню земельних ресурсів в Україні, $\epsilon$ здійснення належного контролю за використанням та охороною земель. Станом на сьогодні ця проблема $\epsilon$ надзвичайно актуальною, оскільки від належного контролю за використанням та охороною земель залежить її ефективне використання.

Окремі питання використання та охорони земель досліджувались у працях С.С. Алексєєва, В.I. Андрейцева, Д.В. Бусуйок, М.Я. Ващишин, Д.Д. Гавриш, А.П. Гетьмана, Ю.Г. Жарикова, Т.О. Коваленко, В.В. Носіка, Т.К. Оверковської, О.О. Погрібного, В.І. Семчика, Т.Є. Харитонової, Ю.С. Шемшученка та інших. Проблеми правового забезпечення управління в сфері використання та охорони земель досліджувались у працях Д.І. Бабміндра, І.Ю. Банашко, Є. Галиновської, Ю.Г. Гуцуляка, О.С. Дорош, П.Ф. Кулинича, А.М. Мірошниченка, А.В. Урсу та інші.

На основі аналізу положень Закону України «Про внесення змін до деяких законодавчих актів України щодо вдосконалення системи управління та дерегуляції у сфері земельних відносин» доведено неефективність правового регулювання використання та охорони земель у контексті останніх законодавчих змін у цій царині з урахуванням децентралізації влади 
та розвитку громадянського суспільства в Україні.

Згідно з Конституцією України [2] земля $\epsilon$ основним національним багатством, що перебуває під особливою охороною держави.

Надання Конституцією України землі статусу основного національного багатства, що перебуває під особливою охороною держави, покладає на органи державної влади, органи місцевого самоврядування загальний обов'язок забезпечити регулювання раціонального використання та охорону земельних ресурсів України.

3 цією метою органи державної влади та органи місцевого самоврядування наділені законодавцем повноваженнями, які $€$ невід'ємним елементом правового статусу будь-якого публічного органу і розуміються в науковій літературі та законодавстві як нерозривна єдність закріплених за органом публічної влади прав та обов'язків. Щодо цього Ц. Ямпольська зазначає, що орган держави не тільки має право, але і зобов'язаний вирішувати покладені на нього завдання, і цей зв'язок прав та обов'язків вона визначила як «правообов'язок» $[3$, с. 5, 9].

Необхідно зазначити, що законодавство України не містить чіткого розуміння поняття «наділення органу повноваженнями». 3 одного боку, ст. 143 Конституції України передбачає, що органам місцевого самоврядування можуть «надаватися законом окремі повноваження органів виконавчої влади», що, на думку деяких науковців, $\epsilon$ тотожним поняттю «надані повноваження» [4, с. 27]. 3 іншого боку, у Законі України «Про місцеве самоврядування в Україні» [5] вживається термін «делеговані повноваження» (статті 27-35, 38).

Погоджуємося з думкою деяких науковців, що поняття «надання повноважень» має більший обсяг, оскільки воно позначає як делегування, так і передачу повноважень [6, с. 76].

Наведена позиція узгоджується з положеннями ч. 1 ст. 4 Європейської хартії місцевого самоврядування [7], в якій йдеться про можливість надання органам місцевого самоврядування відповідно до закону повноважень для виконання кон- кретних завдань, тоді як у ч. 5 цієї ж статті вже передбачена можливість делегування повноважень органам місцевого самоврядування яким-небудь центральним або регіональним органом влади.

Принципова відмінність між передачею повноважень та їх делегуванням полягає у тому, що у разі передачі відповідне повноваження вилучається з компетенції органу виконавчої влади і включається до компетенції органу місцевого самоврядування, тоді як делегування - це надання органом виконавчої влади належного йому за законом повноваження вирішувати те чи інше питання органу місцевого самоврядування за згодою останнього [8, с. 29].

На думку деяких науковців, передача повноважень органів виконавчої влади у сфері земельних відносин органам місцевого самоврядування об'єднаних територіальних громад можлива лише у формі делегування законом. Їх передача у формі власних рішень призведе до незаконного втручання у справи держави [6, с. 76].

Досвід країн Європейського Союзу свідчить про ефективність проведеної реформи децентралізації влади. Так, для федеративної системи Німеччини характерна значна концентрація законодавчих повноважень на федеральному рівні і майже повна децентралізація влади шляхом передачі великого обсягу повноважень на рівень місцевого самоврядування земель [9, с. 197]. Це здійснювалося шляхом проведення у 90-х роках функціональних реформ на рівні об'єднання муніципалітетів та округ, метою яких було скорочення державних органів на місцях та посилення багатофункціональності органів місцевого самоврядування [9, с. 200].

Доленосним кроком на шляху реформи місцевого самоврядування в Польщі було прийняття нової Конституції Польщі 1997 р., у якій було встановлено, що територіальна організація Республіки Польща забезпечує децентралізацію державної влади (ст. 15). Суть децентралізації в Польщі полягала у передачі завдань, компетенцій та повноважень, фінансових активів і коштів із центрального рівня на рівень місцевого самоврядування. Також ґмінам (самоврядні громади) було надано самостійний правовий статус і передано право власності 
[9, с. 261]. Позитивні результати проведеної децентралізації мають місце і у Великій Британії, Франції, Австрії, Швеції, Угорщини та країнах Балтії.

Як відзначає А.П. Гетьман, метою контролю за використанням та охороною земель, що збігається з метою усієї екологічної діяльності, $є$ задоволення справедливих соціальних, економічних, екологічних потреб нинішнього і майбутнього поколінь у сфері розвитку й охорони навколишнього природного середовища [10].

Основною причиною недостатньої ефективності земельних відносин та землекористування в Україні $\epsilon$ нераціонально побудована система державного управління земельними ресурсами. Недоліками сучасної системи державного контролю сфери земельних відносин в Україні доцільно вважати: діяльність органів, уповноважених на здійснення контролю, переважно $€$ реакцією на зловживання у сфері землекористування, проте недостатньо проводяться превентивні заходи; контрольні функції сфери земельних відносин досить часто покладаються на органи, які здійснюють управління ними; відсутність дієвого механізму самоврядного контролю за використанням і охороною земель; відсутність належного державного контролю за особливо цінними ґрунтами [11, с. 70]. Тут потрібно зазначити, що малоактивним виявляться вплив саме громадянського суспільства у цю сферу за наявних механізмів впливу на перебіг реформ та контролю на місцях. Але це окрема тема для більш детального вивчення.

Виконання контрольних функцій у сфері земельних відносин, зокрема здійснення контролю за використанням та охороною земель органами, які здійснюють управління ними, суперечить відомій ще 3 давніх часів правовій аксіомі, відповідно до якої "Nemojudexinresua" («Ніхто не може бути суддею у власній справі»).

Не усунув вказаних недоліків і прийнятий Верховною Радою України 28.04.2021 Закон України № 1423-IX «Про внесення змін до деяких законодавчих актів України щодо вдосконалення системи управління та дерегуляції у сфері земельних відносин» [12] (далі - Закон).

Фактично, положеннями вказаного Закону збережено наявну натепер модель системи державного управління, контролю і нагляду у сфері використання та охорони земель, відповідно до якої у центрального органу виконавчої влади, що реалізує державну політику у сфері земельних відносин (на даний час - Державної служби України з питань геодезії, картографії та кадастру), зберігаються функції державного управління та державного контролю за реалізацією державного управління у цій галузі (нова редакція пункту «е» статті 15-1, частини першої статті 188 Земельного кодексу України, частини першої статті 5 Закону України «Про державний контроль за використанням та охороною земель»).

Отже, згаданим Законом не усунуто концентрацію в одного і того ж суб'єкта владних повноважень управлінських, контрольних та наглядових повноважень із збереженням наявної натепер моделі державного управління і регулювання у сфері земельних відносин.

Разом із цим вказаним Законом здійснення державного контролю за використанням та охороною земель у межах та порядку, встановлених законом, віднесено також до делегованих повноважень виконавчих органів сільських, селищних, міських рад, а в законодавче поле введено новацію із запровадження у виконавчих комітетах сільських, селищних та міських рад інституту державного інспектора з контролю за використанням та охороною земель сільських, селищних та міських рад, якому надається право розглядати справи про адміністративні правопорушення від імені виконавчих комітетів (виконавчих органів) сільських, селищних, міських рад та накладати адміністративні стягнення за такі правопорушення. При цьому виконавчі органи місцевих рад здійснюватимуть зазначене повноваження лише у разі прийняття сільськими, селищними, міськими радами відповідних рішень (абзац другий нової редакції частини першої статті 188 Земельного кодексу України).

Водночас положеннями статті 5 Закону України «Про державний контроль за використанням та охороною земель» [13] передбачається, що державний контроль за використанням та охороною земель усіх категорій та форм власності здійснює центральний орган виконавчої влади, що реа- 
лізує державну політику у сфері земельних відносин, а також виконавчі органи сільських, селищних, міських рад у межах повноважень, визначених законом, у разі прийняття відповідною радою рішення про здійснення такого контролю.

Таким чином, повноваження центрального органу виконавчої влади ставляться в залежність від рішень представницьких органів місцевого самоврядування.

Відтак передбачений згаданим Законом законодавчий підхід з реалізації пропонованої концепції децентралізації влади у сфері земельних відносин, на нашу думку, $\epsilon$ суперечливим, а втілена у вказаному Законі модель здійснення управління у сфері земельних відносин: по-перше, не відповідає статті 1 Конституції України, відповідно до якої Україна $\epsilon$ правовою державою, конституційній моделі організації влади (статті 6, 7, 19, 143 Конституції України); по-друге, порушує закладену Конституцією України та Законом України «Про місцеве самоврядування в Україні» логіку формування повноважень місцевих рад, оскільки за Конституцією України діяльність органів державної влади інституційно та функціонально відокремлена від діяльності органів місцевого самоврядування, тобто від діяльності територіальної громади, яка реалізує своє право як безпосередньо, так і через органи місцевого самоврядування (частина третя статті 140); по-третє, не містить належних правових механізмів її реалізації, зокрема щодо фінансування у повному обсязі державою делегованих нею органам місцевого самоврядування окремих повноважень органів виконавчої влади, що також не відповідає принципу верховенства права (стаття 8 Конституції України).

Відповідно до Конституції України органам місцевого самоврядування законом можуть надаватися окремі повноваження органів виконавчої влади; держава фінансує здійснення цих повноважень у повному обсязі за рахунок коштів Державного бюджету України або шляхом віднесення до місцевого бюджету у встановленому законом порядку окремих загальнодержавних податків, передає органам місцевого самоврядування відповідні об'єкти державної власності; органи місцевого самоврядування з питань здійснення ними повноважень органів виконавчої влади підконтрольні відповідним органам виконавчої влади (частини третя і четверта статті 143) та діють виключно на підставі, в межах повноважень та у спосіб, що передбачені Конституцією та законами України (частина друга статті 19). Відповідно до статті 67 Закону України «Про місцеве самоврядування в Україні» держава фінансово забезпечує здійснення органами місцевого самоврядування наданих законом повноважень органів виконавчої влади у повному обсязі; рішення органів державної влади, які призводять до додаткових видатків органів місцевого самоврядування, обов'язково супроводжуються передачею їм необхідних фінансових ресурсів; вказані рішення виконуються органами місцевого самоврядування в межах переданих їм фінансових ресурсів.

Крім того, на наш погляд, вказаний вище Закон не встановлює й ефективного громадського контролю за використанням та охороною земель.

Конституція України закріплює вихідний принцип громадянського суспільства, згідно з яким суспільне життя в Україні ґрунтується на засадах політичної, економічної та ідеологічної багатоманітності (частина перша ст.15).

Тобто громадянське суспільство можна розглядати як самоорганізовану і саморегульовану сферу публічно-правових відносин у державі, утворювану вільними і рівними індивідами та створеними ними об'єднаннями громадян, які функціонують, формуючи соціальний капітал та, здійснюючи контроль за органами державної влади, служать підґрунтям демократії та визначальним чинником у розбудові правової держави.

Визначальними для ідентифікації правосуб'єктності інститутів громадянського суспільства $\epsilon$ правові форми їх діяльності. У цьому контексті особливого значення набуває проблема взаємодії інститутів громадянського суспільства з органами державної влади України.

Так, відповідно до абзацу другого пункту 2 Порядку сприяння проведенню громадської експертизи діяльності органів виконавчої влади, затвердженого постановою КМУ № 976 [14], до інститутів 
громадянського суспільства віднесено: громадські організації, професійні та творчі спілки, організації роботодавців, благодійні і релігійні організації, органи самоорганізації населення, недержавні засоби масової інформації та інші непідприємницькі товариства і установи, легалізовані відповідно до законодавства.

Аналогічне розуміння форм участі інститутів громадянського суспільства (громадські об'єднання, релігійні, благодійні організації, творчі спілки, професійні спілки та їх об'єднання, асоціації, організації роботодавців та їх об'єднання, органи самоорганізації населення, недержавні засоби масової інформації, інші непідприємницькі товариства та установи, легалізовані відповідно до законодавства) в управлінні державними справами міститься у пункті 7 Порядку проведення консультацій 3 громадськістю 3 питань формування та реалізації державної політики, затвердженому постановою КМУ від 3 листопада 2010 р. № 996 «Про забезпечення участі громадськості у формуванні та реалізації державної політики» [15].

Намірами щодо здійснення інститутами громадянського суспільства громадського контролю у сфері земельних відносин можна було б вважати положення статті 190 Земельного кодексу України [16].

Так, згідно із вказаною статтею громадський контроль за використанням та охороною земель здійснюється громадськими інспекторами, які призначаються центральним органом виконавчої влади, що реалізує державну політику у сфері земельних відносин, центральним органом виконавчої влади, що реалізує державну політику із здійснення державного нагляду (контролю) у сфері охорони навколишнього природного середовища, відповідними органами місцевого самоврядування і діють на підставі положень, затверджених відповідно центральним органом виконавчої влади, що забезпечує формування державної політики у сфері земельних відносин, центральним органом виконавчої влади, що забезпечує формування державної політики у сфері охорони навколишнього природного середовища, відповідною радою.

Проте суперечливим виглядає положення вказаної статті щодо призначення громадських інспекторів центральним органом виконавчої влади, що реалізує державну політику у сфері земельних відносин, центральним органом виконавчої влади, що реалізує державну політику із здійснення державного нагляду (контролю) у сфері охорони навколишнього природного середовища, або відповідним органом місцевого самоврядування, які де-факто та де-юре $\epsilon$ органами влади, тоді як громадянське суспільство $€$ певним протиставленням владним органам.

(Аналіз сутності і змісту) Сутність і зміст наведених правових актів, що регулюють відносини між громадськістю та органами влади, дозволяють зробити висновок (стверджувати), що сучасне українське (чинне) законодавство у цій царині формально (за формальними ознаками) відповідає вимогам, що ставляться до сучасних демократичних держав, створюючи всі необхідні передумови для самостійного вирішення громадськістю питання призначення громадських інспекторів у сфері використання та охорони земель, без втручання держави у цей процес.

Водночас нормативно-правові акти у сфері контролю за використанням та охороною земель в Україні, і зокрема Закон України «Про внесення змін до деяких законодавчих актів України щодо вдосконалення системи управління та дерегуляції у сфері земельних відносин», не враховують положень законодавства у сфері розвитку громадянського суспільства в Україні, тому законодавчі норми щодо реалізації громадськістю повноважень щодо громадського контролю за використанням та охороною земель виглядають лише декларативними.

Прийняття Закону України «Про внесення змін до деяких законодавчих актів України щодо вдосконалення системи управління та дерегуляції у сфері земельних відносин» не усунуло недоліки правового регулювання відносин у сфері використання та охорони земель, зокрема щодо концентрації в одного і того ж суб'єкта владних повноважень - Держгеокадастру, управлінських, контрольних та наглядових повноважень у сфері земельних відносин. Запропонована Законом модель контролю за використанням та охороною земель $\epsilon$ суперечливою, не враховує конституційний принцип формування 
повноважень органів місцевого самоврядування, не містить належних правових механізмів фінансування делегованих державою повноважень щодо контролю за використанням та охороною земель. Крім того, новації вказаного Закону не враховують принципи функціонування інститутів громадянського суспільства, правові форми їхньої участі в управлінні державними справами.
Перспективою подальших наукових розробок у напряму порушених проблемних питань може бути використання отриманих результатів у наступних дослідженнях для удосконалення правового регулювання відносин у сфері використання та охорони земель для реформування системи державного управління та дерегуляції у сфері земельних відносин.

\section{ЛITЕРАТУРА:}

1. Про схвалення Концепції реформування місцевого самоврядування та територіальної організації влади в Україні: розпорядження Кабінету Міністрів Україні від 01.04.2014 p. № 333-p. URL: https://zakon.rada.gov.ua/laws/show/333-2014-p.

2. Конституція України : Закон України від 28.06.1996 р. № 254. URL: https:// zakon.rada.gov.ua/laws/show/254\%D0\%BA/96-\%D0\%B2\%D1\%80\#Text.

3. Ямпольськая Ц.А. Субъекты советского административного права : автореф. дис. ... докт. юрид. наук : 12.00.11. М., 1958. 35 с.

4. Конституція України. Науково-практичний коментар. Харків : Право. 2003. 806 с.

5. Про місцеве самоврядування в Україні : Закон України від 21.05.1997 р. № 280/97-ВР. URL: https://zakon.rada.gov.ua/laws/show/280/97-вр.

6. Майданник О., Оніщук Ю. Правові аспекти механізму передачі деяких повноважень у сфері земельних відносин органам місцевого самоврядування об'єднаних територіальних громад. Вісник Академії праці та соціальних відносин. 2020. № 1-2. С. 71-79. URL: https://www.socosvita.kiev.ua/sites/default/files/Visnyk_1-2_2020-71-79.pdf.

7. Європейська Хартія місцевого самоврядування від 15.10 .1985 p. URL: https:// zakon.rada.gov.ua/laws/main/994_036.

8. Бублик Г.В. Правове регулювання делегованих повноважень за законодавством України. Юридична Україна. 2004. № 8. С. 28-31.

9. Чернеженко О.М. Місцеве самоврядування в України та державах-учасницях $\in$ : конституційне регулювання й організаційні моделі : монограф. Київ : Видавництво: Ліра-К. 2018. 380 c.

10. Гетьман А. Процедура реалізації матеріальних норм у галузі екологічного контролю [Текст]. Вісник Академії правових наук України. 1999. №2. С. 86-92.

11. Паутова Т.О., Шарий Г.І. Земельна реформа в Україні: актуальність, проблеми та перспективи реалізації. Інвестиції: практика та досвід. № 15. 2017. С. 69-73. (Серія: «Державне управління»).

12. Про внесення змін до деяких законодавчих актів України щодо вдосконалення системи управління та дерегуляції у сфері земельних відносин : Закон України від 28.04.2021 № 1423-IX. URL: https://zakon.rada.gov.ua/laws/show/1423-20\#n395.

13. Про державний контроль за використанням та охороною земель : Закон України від 19.06.2003 р. № 963-IV. URL: https://zakon.rada.gov.ua/laws/main/963-15.

14. Порядок сприяння проведенню громадської експертизи діяльності органів виконавчої влади // постанова Кабінету Міністрів України від 5 листопада 2008 р. № 976. URL: https:// zakon.rada.gov.ua/laws/show/976-2008-\%D0\%BF\#Text.

15. Порядок проведення консультацій з громадськістю з питань формування та реалізації державної політики : Постанова Кабінету Міністрів України від 3 листопада 2010 р. № 996. URL: https://zakon.rada.gov.ua/laws/show/996-2010-\%D0\%BF\#Text.

16. Земельний кодекс України : Закон України від 25.10.2001 р. № 2768-III. URL: https:// zakon.rada.gov.ua/laws/show/2768-14. 